\title{
Study on Piano Assessment Model of Performance Taking the Place of Examination in Higher Normal Colleges under the New Situation
}

\author{
Gaoyang Liu \\ Sichuan University of Arts and Science \\ Dazhou, China 635000
}

\begin{abstract}
With the development of the times, the demand for talents of society has become more and more multi-skilled. Comprehensive and applied talents have become the common goal for higher teacher training students, of which musical majors with strong skills are particularly prominent. Academia have in-depth and comprehensive analysis on piano, the core course of music majors in higher normal colleges, of the knowledge theories, performance techniques, classroom models, and use of teaching materials on piano. The discussion of its core orientation-evaluation model, in turn, is rare. This article starts from the social needs and analyzes the scientificity, operability, and universality of assessment model of performance taking the place of examination, and concludes that it can improve students' various skills, facilitate their employment, and meet new social needs.
\end{abstract}

Keywords-piano; assessment mode; performance taking the place of examination; meaning

\section{INTRODUCTION}

The development of piano has a history of more than 300 years. Whether it is from the Baroque period to Modern times, or the earliest harpsichord to modern piano nowadays, its unique artistic charm has widely influenced music lovers in various countries. When the piano enters the classroom as arts, its unique social functions, artistic values, and modes of transmission have all been more fully embodied. In the new era, what kinds of piano talents are required by the society raises new requirements for the cultivation direction of higher teachers, and the piano assessment model often elbow or even has negative effect on the direction of piano talent training. The traditional piano examination can no longer meet the needs of the new era of the society. It makes the exploration of piano evaluation mode has very important significance.

\section{NEW REQUIREMENTS OF SOCIETY FOR PIANO TEACHERS}

\section{A. Good Ideological Quality, Strong Professional Skills}

Good ideological morality is an important guarantee for teachers who work as engineers of human souls. "Knowledgeable, one can be a teacher, and with noble character, one can be a model", without noble characters, he cannot restrain himself, without right attitude, he cannot engage in scholarship well. A good teacher must have good style, good character, and a sound personality. He should dare to take the responsibility, be willing to sacrifice, and be strict with himself. Only in this way can we teach knowledge well, educate people well, lead troops well, and fight battles well. Especially in the new era, people's pursuit of materialism, fame and wealth is expanding; ideology and morality decline, and values and aesthetics have deviated from their tracks. At this time, putting the thinking quality in the first place is the necessity of education and the needs of the situation.

"It is necessary to be willing to do, to be able to do and to do a good thing". Without action, the ideal cannot be achieved. As a piano teacher, solid professional competence is an important guarantee for successful teaching. This is manifested in the followings: Firstly, he should have a solid level of piano performance, and can play various pieces of works such as the etude, sonata, polyphony, and music. (Different qualifications have different requirements), and can shape the music image accurately and express the thoughts and feelings based on the work styles, the requirements of writers. Secondly, he should have ability of skilled accompaniment, not only capable of analyzing and playing the ortho-spectrum accurately, but also orchestrate and impromptu accompanying for the simple spectrum. Thirdly, he should have strong abilities of piano teaching, capable of normative guiding and training on students integrated and ruminated with knowledge in order to achieve the purpose of applying. Although the piano in normal college is different from that in the professional conservatory of music, however, with the increasing number of little musicians and the unceasing enhancement of overall levels, piano teachers are required to constantly lay solid foundations for music, improve performance and accompaniment level, and optimize piano teaching.

\section{B. Rich Practical Experience and Balanced Comprehensive Ability}

The rich practical experience and balanced comprehensive ability are other requirements of the society for piano teachers in the new era. With the diversified, cutting-edged, informationized and industrialized 
development of music, what piano teachers faced is not only simple classroom teaching, but also many music-related or even unrelated issues. Such as stage design, lighting usage, clothing choices, programs selection, host selection and training... It is difficult to complete well without rich practical experience and balanced comprehensive abilities. Especially in some primary and secondary schools, piano teachers often serve as head teachers, dance teachers, recital teachers, art teachers, and other roles. This reflects the scarcity of piano professionals and raises new requirements for piano training in normal universities.

\section{ThE TRAINING OF PIANO TEACHERS IS AFFECTED BY THE ASSESSMENT MODEL}

\section{A. It Has an Impact on the Setting and Development of the Course}

The developing of the piano curriculum directly affects the cultivation of piano teachers, and the piano assessment mode has an important positioning function in the opening of the piano curriculum. At present, the piano assessment mode in normal colleges is divided into examinations and inspections by nature. Examinations generally include final exams, completion, and graduation examination, and inspections often refer to ordinary classes; examinations by type are often divided into exams for Elite-Oriented, major exams, promotion exams, make-up exams, deferment exams, etc.; exams by methods are divided into individual exams, group exams, collective exams. However, no matter what kind of examinations, they are basically the tests of teaching quality, the examination of the depth and breadth of knowledge and the assessment of curriculum developing. Different assessment methods will guide the opening and developing of courses. For example, the solo examination will promote the progress of the piano performance courses, the accompaniment examination will promote the development of piano arts instruction courses, and the concerto examination will affect the establishment of related instrumental music courses.

\section{B. It Has Influence on Methods and Attitudes of Teaching}

Different assessment modes will also affect teaching methods and attitudes. When testing sonatas, teachers will focus on teaching knowledge theory, style characteristics, and skills of sonatas; when it refers to etudes, teachers will focus on the training of students' basic skills. Although many exams are comprehensive, teachers often select teaching methods based on the contents, methods, and nature of examinations. The negative phenomena that some teachers "teach comprehensively for large-scaled examination", "teach negatively for small-scaled examination", "do not teach without examination", "teach seriously for collective examination", "teach more for group tests", and "teach less for tests organized by themselves" occur. The corresponding methods and attitudes are the respond to evaluation modes. Although teaching are not all like those, affecting by scores and ranking, the ways and attitudes of teaching are necessarily subject to checks and balances.

\section{It Guides Students' Direction and Goals}

There is no doubt that the piano assessment model guides students' learning direction. Whether it is the selection of music tracks, the classification of technologies, or the methods, attitudes, abilities, understandings, thinking, and other aspects, all factors are influenced by the piano assessment modes. Some colleges rarely test polyphony, and students will not take the initiative to practice the tracks in this area. Even in the four years of college studying, students has never played polyphony. Some colleges set up test music tracks in the beginning of term, and the entire semester are spent on explaining the exam works, causing that students only can play a few pieces of music in the four years of university, but ignores the exercises of basic training and accumulation of tracks; what's more, some college teachers organize examination by themselves, and the test scores all depend on students' relationship with their teacher making students go back doors and even lead to problems on thought quality and moral consciousness, which affects students' life direction and behavioral norms.

\section{Piano Assessment Model - Performance TAKING THE PLACE OF EXAMINATION}

\section{A. Performance Taking the Place of Examination}

"Performance taking the place of Examination" is a new evaluation model based on the traditional tests combined with the needs of the society. The core of the mode is replacing tests by performance measured in classes. Its fundamental purpose is to exercise students' comprehensive ability, improve their practicality, and meet multiple requirements of the state and society for talents. The examination methods are divided into four parts: preparatory preparation, concerts, performance evaluation, and summary report.

The preliminary preparation includes the selection of tracks, the mastery of the number of people, the control of time, the selection of hosts, the production of the program and posters, the selection of costumes, and the design of the choreography. The entire process is basically in charge of the student themselves (the choice of track is based on the test outlines combined with the advice of professional instructors).

The concert is an important part of the "Performance taking the place of Examination", and is an important part of the students focusing on demonstrating their own performance level, their ability to comprehend works, their control ability, and their work completion. According to the corresponding provisions of teaching program, the forms of tests can be performing a solo, concerto, or make artistic instruction; playing a single piece of work or multiple pieces of work (taking average score); may playing an etude, a piece of music or polyphony, a sonata, and performing measured in classes. The change from traditional exams to performances requires that students have more solid basic skills, more complete interpretations of their works, more beautiful tones, more accurate emotional expression, and appealing stage effects. This is not only an examination of 
students' professional ability but also a guide, but a teaching assessment for teachers.

The test grades include concert performances (70\%), peacetime accomplishments (20\%), and comprehensive investigations (10\%). Concert performances are collectively scored and averaged by the piano teachers. The usual grades are assessed according to the student's usual class attendance, class motivation, concentration, and class quality. The comprehensive inspection is to evaluate students' program and posters design, costumes matching, choreography design, overall organization of the concert, and summary reports. In each session of scoring, teachers and students are required to sign and the concert is videotaped. The entire process is fair, impartial and factual.

The summary report requires students to conduct a thorough and in-depth analysis of the entire process, identify weaknesses and improve them, continue to develop the merits, and formulate learning and performance plans for the next semester based on their actual situation and learning direction. The word count of the report is required to be above 2000 words and it is stored into the student's personal database along with study plans of every semester.

\section{B. The Feasibility of Performance Taking the Place of Examination}

Since the reform and opening up, the level of material life has been increasing and people are getting richer and richer. For music majors, they are fully capable of paying all costs related to the show; there is also plenty of time to think about, plan, and implement all aspects of the entire show, coupled with a strong body, quick thinking, and a curious mindset; those all make "Performance taking the place of Examination" a great expectation for students.

\section{The Scientificity of "Performance Taking the Place of Examination"}

The assessment model of "performance taking the place of examination" has strong scientificity. It mainly reflects in the following three aspects. First, it meets the requirements of the State Ministry of Education for colleges and universities, and it designs combined with the physical and mental development of students according to the actual conditions of students; Second, college facilities, teaching staff and students ability are fully taken into consideration in the implementation process; Third, the text mode is summarized, improved and progressed continually. Fourth, the test score is scientific, specific and reasonable, and it can not only examine the students' ability of piano performance and accompaniment, but also a comprehensive test of the overall quality of students.

\section{Extensiveness of "Performance Taking the Place of Examination"}

There are several aspects to the extensiveness of "Performance taking the place of Examination". Firstly, it applies to majors of various professional skills. Whether it is vocal music, instrumental music or dance, even the broadcasting and hosting can use the form. Second, it is suited to students of different degrees and grades. Whether junior college students or undergraduate students, general students or major students, higher vocational colleges or ordinary normal colleges, schools of different type or in different geographical areas, all of them can take or organize the test.

\section{THE SIGNIFICANCE OF PERFORMANCE TAKING THE PLACE OF EXAMINATION UNDER THE NEW SITUATION}

\section{A. Students' Comprehensive Abilities Are Improved}

The piano evaluation mode of "performance taking the place of examination" not only optimizes the students' piano learning mode, improves the students' enthusiasm and professionalism, but also improves the students' comprehensive abilities effectively. First, mental quality is improved. As the examination is put on the stage and the examination becomes a performance, students will face more audiences and feel more attention on them. At the same time, their psychological feelings will be obviously different. They will pay more attention to their own actions and care about their own sounds. Besides, they are more focused and emotional. From preparation, observing, standing onstage to performing, the whole process for students is not only a journey of the heart but also the process of improving psychological quality. Second, the coordination ability is greatly improved. Whether it is from music selection to performance, clothing selection to appear on the stage formally, or the program design to the final draft are all inseparable from communicating with others. In this way, the coordination ability of students will be greatly improved. Third, the innovation ability is improved. During the whole process, in addition to works teaching and handling guided by teachers, the rest is completely planned and directed by students themselves. It enables students to make better designs on all aspects referring to other performances, to reflect their own characteristics, highlights, which is not only a test of students' aesthetic consciousness, but also the cultivation of their innovative thinking ability. Fourth, the practical ability of the whole process is well exercised. "Reading thousands of books is inferior to walking thousands of miles" and "futility is not worth worrying about, action is what people afraid of." Action is the guide, and action is the key. The entire process is the best platform for improving practical ability.

\section{B. It Is Conducive to Student Employment}

As we all know, the piano course in normal college is the most important major course in musical majors. Whether it is vocal music, solfeggio, or composition, all this cannot be separated from piano. Many employers firstly inspect students' ability to piano playing and accompaniment, and next is comprehensive ability. This is inseparable from regular activities of schools such as chorus competitions, instrumental music groups, and music salons. As the assessment model is changed to "performance taking the place of examination", organizing ability, operational ability, and coordinate ability of students are fully exercised. They can adapt to work quickly and receive a favorable response 
by colleagues and leaders. Taking the Sichuan University of Arts and Science as an example, since it took the lead in the Sichuan Normal University to implement the assessment mode of "performance taking the place of examination", it has been widely welcomed by teachers and students, and has also gotten highly praised by the colleges and universities. In the meanwhile, it has also received positive feedback from employers.

\section{It Meets New Need of Society}

According to the requirements of the "13th Five-Year Plan" for the Development of the National Education Development, it's an important agenda for cultivating complex, innovative and applied talents in China. Since the founding of New China, politics, economy, culture, and education have all undergone continuous reform and practice. From the initial period of the founding of the People's Republic of China, the construction period after the Cultural Revolution, to the development period of reform and opening up, the demand for talents in society is constantly being updated. Since the reform and opening up, although political economy, science and technology, and cultural education have all achieved great progress, the lack of complex, innovative, and applied talent still exists. It's the need of society, employers, and higher teacher cultivation to solve the problem.

\section{CONCLUSION}

The power of the state depends on talents, and the power of talents depends on education, and education is an enduring prosperity. What kinds of people are cultivated, how cultivate them, and who they are cultivated for, all those pose serious questions for educators nowadays. Following the prescribed order, being an armchair strategist on paper can only cultivate single people with knowledge and skills. As a piano evaluation model for higher teachers, "performance taking the place of examination" can not only assess and promote the professional level of students, but also test and train students' other abilities, and guide the direction and goals of students' learning simultaneously. It is not only an examination method, but also a practical activity. It can not only improve students' professional levels, but also cultivate their aesthetic ability and creative ability. It is not only the training for students' ability of coordination and communication, but also the leading of students' ideology and morality as well as behavioral norms.

Under the new situation, every educator shoulders the new mission of the times. In the education new journey of following original hearts, forging ahead, and being not afraid of innovation and reforms, the piano evaluation mode of "performance taking the place of examination" in normal colleges and universities can give full play to its social functions and cultivate more complex and applied talents for the society with its characteristics of scientificity, universality and feasibility.

\section{REFERENCES}

[1] Zhou Fengwu. Talking on the teaching of music education in normal universities, J. Education and Vocation. 2009 (09): 116-117. 周凤武. 谈高师音乐教育专业钢琴教学 [J]. 教育与职业.2009（09）：116 117.

[2] Mao Ziping. Talking on the evaluation of piano teaching in normal colleges, J. Art Education. 2015(04):80. 毛自平.也谈高师钢琴教学 评价 [J].艺术教育. 2015（04）：80.

[3] Sun Jingya. Status survey and Analysis on Examination assessmen system of Piano Majors,J. Music Space. 2016(04):142-147. 孙静雅. 钢琴主科专业考试测评制度现状调查与分析 [J]. 音乐时空. 2016(04): 142-147.

[4] Sha Sha. A Preliminary Study on the Evaluation Mode Reform of Music Piano Examination of Normal Universities in Xinjiang, J. Popular Culture \&Arts. 2014 (01): 230-231. 沙莎.新疆高师音乐学 钢琴考试评价模式改革初探[J].大众文艺. 2014（01）：230-231.

[5] Huang Lan. Sidelights on piano professional examination of higher teachers in local normal universities, J. Art Science and Technology. 2016. (09): 375. 黄兰. 地方高师钢琴专业课考试侧记 [J].艺术科 技.2016. (09)： 375 .

[6] Yang Yang. The construction and application of piano multiplex teaching evaluation model of normal universities, J. musical creation. 2017(10): 175-177. 杨洋. 高师钢琴多元化教学评价模式的建构与 应用[J].音乐创作.2017 (10)：175-177.

[7] Sun Lanlan. Reflections on the Piano Examination System Reform, J Theory Horizon. 2004(06): 230. 孙岗岗.关于钢琴考试制度改革的 思考 $[\mathrm{J}]$.理论界.2004（06）:230 